\title{
SUBSTRATE SPECIFICITY OF THE HUMAN CORONAVIRUS 229E 3C-LIKE PROTEINASE
}

\author{
John Ziebuhr, Gerhard Heusipp, Anja Seybert, and Stuart G. Siddell \\ Institute of Virology \\ University of Würzburg \\ Versbacher Strasse 7 \\ 97078 Würzburg, Germany
}

\section{ABSTRACT}

Coronavirus gene expression involves proteolytic processing of the gene 1-encoded polyproteins and a key enzyme in this process is the virus-encoded $3 \mathrm{C}$-like proteinase. In this study, we describe the biosynthesis of the human coronavirus 229E 3C-like proteinase in Escherichia coli and the substrate specificity of the purified protein. Using immunofluorescence microscopy, we have also investigated the subcellular localization of the 3C-like proteinase and have found a punctate, perinuclear distribution of the proteinase in virus-infected cells.

\section{INTRODUCTION}

The human coronavirus (HCV) 229E genome is a positive-strand RNA of approximately 27,000 nucleotides. The replicase gene or gene 1 , which is located at the 5 ' end of the genome, is comprised of two large, overlapping open reading frames (ORFs), ORF la and ORF $1 \mathrm{~b}$. The upstream ORF, ORF 1a, encodes a polyprotein, ppla, with a calculated molecular mass of $454 \mathrm{kDa}$. In vitro studies suggest that the downstream ORF, ORF $1 \mathrm{~b}$, is expressed as a fusion protein with the ORF 1a-derived polyprotein ppla by a process of $(-1)$ ribosomal frameshifting. The fusion protein, pplab, has a calculated molecular mass of $754 \mathrm{kDa}$ (Herold et al., 1993; Herold and Siddell, 1993).

There is clear evidence that the functional polypeptides involved in coronaviral RNA replication are released from the replicase gene-encoded polyproteins by extensive proteolytic processing. A key enzyme in this process appears to be the virus-encoded 3Clike proteinase (Liu et al., 1997; Heusipp et al., 1997a, 1997b; Grötzinger et al., 1996; Lu 
et al., 1996; Tibbles et al., 1996; Ziebuhr et al., 1995; Liu et al., 1994). Recently, considerable progress has been made in characterizing the enzymatic properties of the coronavirus $3 \mathrm{C}$-like proteinase and it appears that the enzyme has a catalytic system which is similar to the picornavirus $3 \mathrm{C}$ proteinases. However, the coronavirus enzyme has also several additional, unique features (Ziebuhr et al., 1997; Lu and Denison, 1997; Seybert et al., 1996; Lu et al., 1995; Liu and Brown, 1995; Ziebuhr et al., 1995).

In infected cells, the 3C-like proteinases of mouse hepatitis virus (MHV) A59 and HCV 229E have been identified as polypeptides with apparent molecular masses of 27 $\mathrm{kDa}$ and $34 \mathrm{kDa}$, respectively ( $\mathrm{Lu}$ et al., 1996; Ziebuhr et al., 1995). However, to date nothing is known about the subcellular localization of the coronavirus $3 \mathrm{C}$-like proteinase.

\section{MATERIALS AND METHODS}

\subsection{Bacterial Expression and Purification of the HCV 229E 3C-Like Proteinase}

The construction of plasmid pMalc2-3CL and the bacterial expression of the HCV 229E 3C-like proteinase have been described previously (Ziebuhr et al., 1995). Briefly, a fusion protein, MBP-3CLpro, containing the maltose-binding protein (MBP) of $E$. coli and the 3C-like proteinase domain of HCV 229E (amino acids 2966-3267 of ppla and pplab) was synthesized in bacteria and then purified by amylose-affinity chromatography. The authentic 3C-like proteinase was released from the fusion protein by factor Xa cleavage and the protein mixture was loaded onto a Phenylsepharose HP column (Pharmacia Biotech, Freiburg, Germany) that had been pre-equilibrated with $12.5 \mathrm{mM}$ Bis-Tris- $\mathrm{HCl}, \mathrm{pH} 7.0,300$ $\mathrm{mM} \mathrm{NaCl}, 1 \mathrm{mM}$ dithiothreitol, $0.1 \mathrm{mM}$ EDTA. After extensive washing of the column, the recombinant $3 \mathrm{C}$-like proteinase was eluted with $12.5 \mathrm{mM}$ Bis-Tris- $\mathrm{HCl}, \mathrm{pH} 7.0,1 \mathrm{mM}$ dithiothreitol, $0.1 \mathrm{mM}$ EDTA. The fractions containing the 3C-like proteinase were pooled and concentrated to $3 \mathrm{mg} / \mathrm{ml}$ using Centricon-3 concentrators (Amicon, Beverly, Mass.). The concentrated material was purified further by chromatography on a Superdex $75 \mathrm{pg}$ column (Pharmacia Biotech) run under isocratic conditions with $10 \mathrm{mM}$ Tris- $\mathrm{HCl}, \mathrm{pH} 7.3,200$ $\mathrm{mM} \mathrm{NaCl}, 0.1 \mathrm{mM}$ EDTA, $1 \mathrm{mM}$ dithiothreitol. Finally, the purified protein was concentrated to $10 \mathrm{mg} / \mathrm{ml}$ using Centricon-3 concentrators and stored at $-80^{\circ} \mathrm{C}$.

\subsection{Trans-Cleavage Assays}

3.2.1. Peptide Substrates. Synthetic peptides were prepared by solid-phase chemistry and purified by high-performance liquid chromatography (HPLC) on a reversed-phase $\mathrm{C}_{18}$ silica column (Jerini Bio-Tools, Berlin, Germany). The identity and homogeneity of the peptides were confirmed by mass spectrometry and analytical reversed-phase chromatography. Cleavage reactions were incubated for $2 \mathrm{~h}$ at $25^{\circ} \mathrm{C}$ and contained $20 \mathrm{mM}$ BisTris- $\mathrm{HCl}, \mathrm{pH} 7.0,1 \mu \mathrm{M}$ recombinant $3 \mathrm{C}$-like proteinase and $0.5 \mathrm{mM}$ substrate peptide in a total volume of $20 \mu \mathrm{l}$. The reactions were terminated by the addition of $80 \mu \mathrm{l} 0.1 \%$ trifluoroacetic acid and the mixture was centrifuged for $5 \mathrm{~min}$ at $14000 \mathrm{x} g$ prior to analysis by reversed-phase HPLC on a $3.9 \times 150 \mathrm{~mm}$ Delta Pak $\mathrm{C}_{18}$ column (Waters, Milford, Mass.). Cleavage products were resolved using a 22-min, 5-90\% linear gradient of acetonitrile in $0.1 \%$ trifluoroacetic acid. The absorbance was determined at $215 \mathrm{~nm}$. Under these conditions, the conversion of functional substrate peptides was complete. Nonfunctional substrate peptides did not show detectable hydrolysis under the same conditions. 
3.2.2. Fusion Protein Substrates. Fusion proteins consisting of MBP and various replicase gene-derived peptide sequences were synthesized in $E$. coli TB1 cells and purified by amylose-affinity chromatography as described previously (Grötzinger et. al., 1996; Heusipp et al., 1997a; Heusipp et al., 1997b). In this way, five fusion proteins were purified that contain the following gene 1-encoded amino acids (aa): (i) aa 3934-4237, (ii) aa 4774-5259, (iii) aa 5500-5771, (iv) aa 5981-6602, and (v) aa 5981-6290. These substrate proteins were incubated with recombinant $3 \mathrm{C}$-like proteinase as described by Grötzinger et al. (1996). The cleavage products were separated by SDS-polyacrylamide gel electrophoresis, transferred electrophoretically to polyvinylidene difluoride membranes, and the amino-terminal sequences of the carboxyl-terminal cleavage products were determined by automated Edman degradation as previously described (Ziebuhr et al., 1995).

\subsection{Immunofluorescence Assay}

MRC-5 cells were grown on coverslips, infected with HCV 229E (multiplicity of infection of 10 pfu per cell), and incubated at $33^{\circ} \mathrm{C}$. After $15 \mathrm{~h}$, the cells were fixed for 10 min with $4 \%$ paraformaldehyde in PBS. After washing with PBS, the cells were permeabilized with PBS- $0.2 \%$ Triton X-100 and washed with PBS- $1 \%$ NP- 40 . The indirect immunofluorescence assays were carried out with the HCV 229E 3C-like proteinase-specific antiserum K17 (Ziebuhr et al., 1995) at a 1:100 dilution in $10 \mathrm{mM}$ Tris- $\mathrm{HCl}, 150 \mathrm{mM}$ $\mathrm{NaCl}, 1 \% \mathrm{NP}-40$ containing $5 \%$ normal goat serum to reduce the background fluorescence. A FITC-conjugated goat anti-rabbit immunoglobulin G (1:100 dilution, Dianova, Hamburg, Germany) was used as the secondary antibody.

\section{RESULTS AND DISCUSSION}

\subsection{Substrate Specificity of the HCV 229E 3C-Like Proteinase}

Recently, considerable progress has been made in characterizing the primary structure of substrates that are recognized and cleaved by the HCV 229E 3C-like proteinase (Ziebuhr et al., 1997; Heusipp et al., 1997a; Heusipp et al., 1997b; Grötzinger et al., 1996, Ziebuhr et al., 1995). In order to substantiate the conclusions that have been drawn from these experiments, we have extended, in the present study, the analysis of putative functional substrates of the HCV 229E 3C-like proteinase. We have used both synthetic peptides and bacterially synthesized fusion protein substrates in the trans-cleavage assays with recombinant $3 \mathrm{C}$-like proteinase. These data, combined with published results on the substrate specificity of the HCV 229E 3C-like proteinase, are summerized in Table 1 and lead us to the following conclusions. The Gln residue in the $\mathrm{P} 1$ position is absolutely conserved among all $3 \mathrm{C}$-like proteinase substrates identified to date. The $\mathrm{P} 2$ and P1' positions are occupied by Leu/Ile and Ser/Ala/Gly, respectively. However, as Table 1 also shows, the presence of the conserved Leu/Ile-Gln-Ser/Ala/Gly sequence is not sufficient for cleavage by the $3 \mathrm{C}$-like proteinase: Two peptides containing either Ile-Gln-Ser or Ile-Gln-Gly tripeptides are not cleaved. Clearly, proteolysis is not exclusively determined by the P2 through P1' positions. It is also interesting to note, that the HCV 229E $3 \mathrm{C}$-like proteinase cleaves efficiently an MHV-A59 derived peptide substrate indicating that the substrate specificity of coronavirus $3 \mathrm{C}$-like enzymes is, at least to some extent, conserved. 
Table 1. Substrate specificity of recombinant HCV 229E 3C-like proteinase

\begin{tabular}{llllllllllllllllll}
\hline Substrate $^{a}$ & 1110 \\
\hline P & K & T & L & I & F & T & L & Q & $\downarrow$ & A & A & F & G & N & A & G & HCV 229E ppla/lab \\
B/P & V & S & Y & G & S & T & L & Q & $\downarrow$ & A & G & L & R & K & M & A & HCV 229E ppla/lab \\
P & Q & M & F & G & V & N & L & Q & $\downarrow$ & S & G & K & T & T & S & M & HCV 229E ppla/lab \\
B & T & C & D & R & T & A & I & Q & $\downarrow$ & S & F & D & N & S & Y & L & HCV 229E ppla/lab \\
B & Y & E & K & S & T & V & L & Q & $\downarrow$ & A & A & G & L & C & V & V & HCV 229E pplab \\
B/P & E & I & T & M & T & D & L & Q & $\downarrow$ & S & E & S & S & C & G & L & HCV 229E pplab \\
B & T & F & T & E & V & N & L & Q & $\downarrow$ & G & L & E & N & I & A & F & HCV 229E pplab \\
B & A & T & F & Y & P & Q & L & Q & $\downarrow$ & S & A & E & W & K & C & G & HCV 229E pplab \\
P & L & C & T & T & S & F & L & Q & $\downarrow$ & S & G & I & V & K & M & V & MHV-JHM pp la/lab \\
P & C & F & L & V & T & K & F & R & & R & M & F & G & D & L & S & HCV 229E ppla/lab \\
P & D & S & F & C & K & T & I & Q & & S & A & L & S & V & V & S & HCV 229E ppla/lab \\
P & K & Q & R & I & T & T & I & Q & & G & P & P & G & S & G & K & HCV 229E pplab \\
\hline
\end{tabular}

"P, synthetic peptide; $\mathrm{B}$, bacterially synthesized fusion protein.

The cleavage of a specific peptide bond is indicated by an arrow.

\subsection{Intracellular Localization of the HCV 229E 3C-Like Proteinase}

In the case of coronaviruses, there is a paucity of information on the intracellular localization of replicase gene-encoded polypeptides. Therefore, we decided to study the intracellular localization of the $3 \mathrm{C}$-like proteinase by immunofluorescence microscopy. MRC-5 cells were infected with HCV 229E at a multiplicity of infection of 10 pfu per cell, and $15 \mathrm{~h}$ postinfection we performed an indirect immunofluorescence analysis using the proteinase-specific rabbit antiserum K17 (Ziebuhr et al., 1995). The results of this experiment are shown in Figure 1. We observed a punctate, perinuclear immunofluorescence

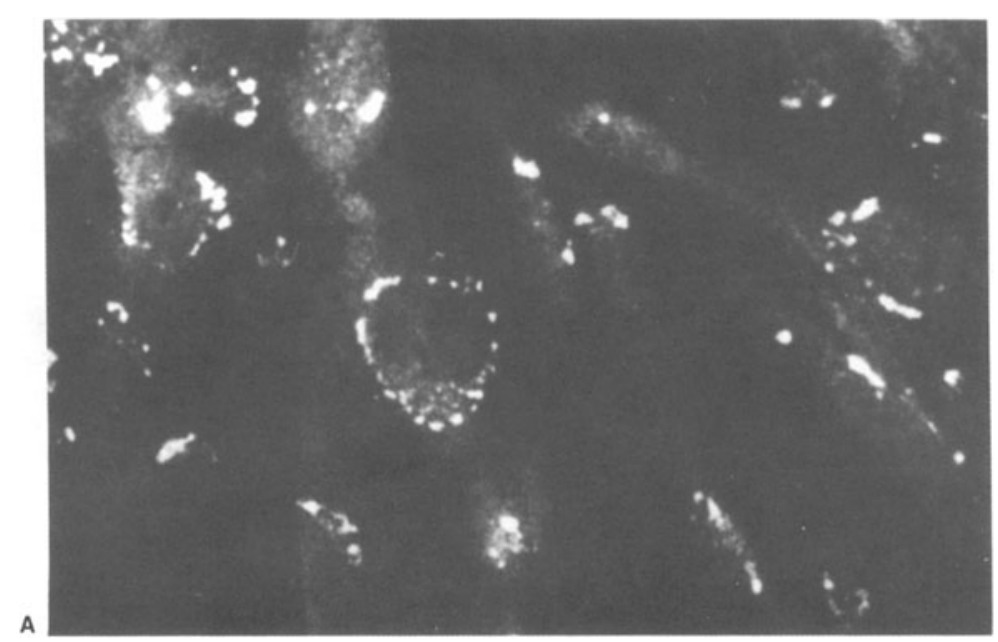

Figure 1. Immunofluorescence analysis of the subcellular localization of the 3C-like proteinase in HCV 229E-infected cells. MRC-5 cells were infected with HCV 229E (panel A) or mock infected (panel B) and analyzed $15 \mathrm{~h}$ postinfection. 


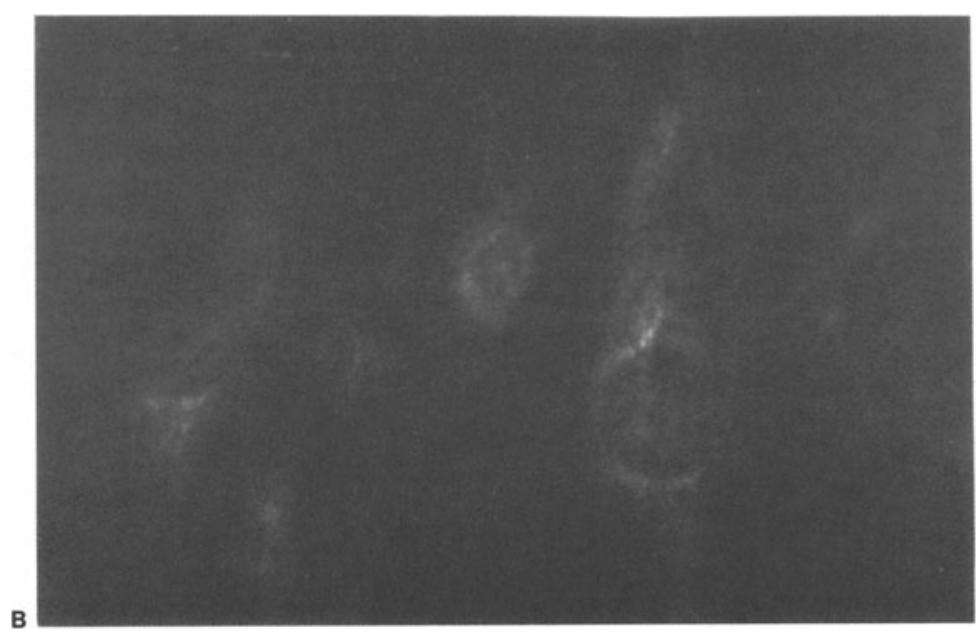

Figure 1B.

in virus-infected cells. A very similar staining pattern was also observed in HCV 229E-infected HeLa-CD13 cells (data not shown). These data provide the first experimental evidence that the coronavirus $3 \mathrm{C}$-like proteinase is located in a perinuclear, presumably membraneous compartment. Interestingly, a similar immunofluorescence pattern has also been reported for the replicase gene-encoded putative helicase and RNA polymerase proteins of the equine arteritis virus (EAV), a virus that is closely related to coronaviruses (van Dinten et al., 1996).

\section{REFERENCES}

Grötzinger, C., Heusipp, G., Ziebuhr, J., Harms, U., Süss, J., and Siddell, S. G., 1996, Characterization of a 105kDa polypeptide encoded in gene $I$ of the human coronavirus HCV 229E, Virology 222: 227-235.

Herold, J. and Siddell, S. G., 1993, An elaborated pseudoknot is required for high frequency frameshifting during translation of HCV 229E polymerase mRNA, Nucleic Acids Res. 21: 5838-5842.

Herold, J., Raabe, T., Schelle-Prinz, B. and Siddell, S. G., 1993, Nucleotide sequence of the human coronavirus 229E RNA polymerase locus, Virology 195: 680-691.

Heusipp, G., Grötzinger, C., Herold, J., Siddell, S. G., and Ziebuhr, J., 1997a, Identification and subcellular localization of a $41-\mathrm{kDa}$, polyprotein lab processing product in human coronavirus $229 \mathrm{E}$-infected cells, J. Gen. Virol., in press

Heusipp, G., Harms, U., Siddell, S. G., and Ziebuhr, J., 1997b, Identification of an ATPase activity associated with a 71-kDa polypeptide encoded in gene 1 of the human coronavirus $229 \mathrm{E}, \mathrm{J}$. Virol., in press

Liu, D. X. and Brown, T. D. K., 1995, Characterization and mutational analysis of an ORF la-encoding proteinase domain responsible for proteolytic processing of the infectious bronchitis virus $1 \mathrm{a} / 1 \mathrm{~b}$ polyprotein, Virology 209: 420-427.

Liu, D. X., Brierley, I., Tibbles., K. W., and Brown, T. D. K., 1994, A 100-kilodalton polypeptide encoded by open reading frame (ORF) lb of the coronavirus infectious bronchitis virus is processed by ORF 1 a products, $J$. Virol. 68: 5773-5780.

Liu, D. X., Xu, H. Y., and Brown, T. D. K., 1997, Proteolytic processing of the coronavirus infectious bronchitis virus la polyprotein: identification of a 10-kilodalton polypeptide and determination of its cleavage sites, J. Virol. 71: 1814-1820. 
Lu, Y. and Denison M. R., 1997, Determinants of mouse hepatitis virus 3C-like proteinase activity, Virology 230: 335-342.

Lu, X., Lu, Y., and Denison, M. R., 1996, Intracellular and in vitro-translated 27-kDa proteins contain the 3C-like proteinase activity of the coronavirus MHV-A59, Virology 222: 375-382.

Lu, Y., Lu, X., and Denison, M. R., 1995, Identification and characterization of a serine-like proteinase of the murine coronavirus MHV-A59, J. Virol. 69: 3554-3559.

Seybert, A., Ziebuhr, J., and Siddell, S. G., 1997, Expression and characterization of a recombinant murine coronavirus 3C-like proteinase, J. Gen. Virol. 78: 71-75.

Tibbles, K. W., Brierley, I., Cavanagh, D., and Brown, T. D. K., 1996, Characterization in vitro of an autocatalytic processing activity associated with the predicted $3 \mathrm{C}$-like proteinase domain of the coronavirus avian infectious bronchitis virus, J. Virol. 70: 1923-1930.

Van Dinten, L. C., Wassenaar, A. L. M., Gorbalenya, A. E., Spaan, W. J. M., and Snijder, E. J., 1996, Processing of the equine arteritis virus replicase ORF1b protein: identification of cleavage products containing the putative viral polymerase and helicase domains, J. Virol. 70: 6625-6633.

Ziebuhr, J., Herold, J., and Siddell, S. G., 1995, Characterization of a human coronavirus (strain 229E) 3C-like proteinase activity, J. Virol. 69: 4331-4338.

Ziebuhr, J., Heusipp, G., and Siddell, S. G. (1997). Biosynthesis, purification, and characterization of the human coronavirus 229E 3C-like proteinase, J. Virol. 71: 3992-3997. 